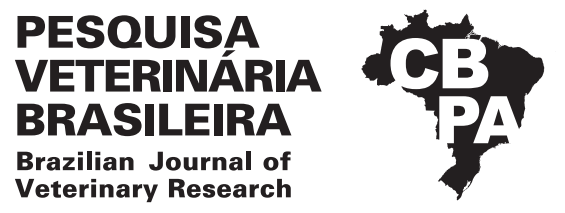

Pesq. Vet. Bras. 39(10):796-801, October 2019 DOI: 10.1590/1678-5150-PVB-6315

Original Article

ISSN 0100-736X (Print)

ISSN 1678-5150 (Online)

\title{
Bacteria isolated from the lower respiratory tract of sheep and their relationship to clinical signs of sheep respiratory disease ${ }^{1}$
}

\author{
Mariane F. Franco ${ }^{2}$, Natália C. Gaeta ${ }^{2 *}$ (D) Mario A.R. Alemán², Priscilla A. Mellville, \\ Jorge Timenetsky ${ }^{4}$, Mário F.A. Balaro ${ }^{5}$ and Lilian Gregory ${ }^{2}$
}

\begin{abstract}
Franco M.F., Gaeta N.C., Alemán M.A.R., Mellville P.A., Timenetsky J., Balaro M.F.A. \& Gregory L. 2019. Bacteria detected from the lower respiratory tract of sheep and their relationship to clinical signs of sheep respiratory disease. Pesquisa Veterinária Brasileira 39(10):796-801. Departamento de Clínica Médica, Faculdade de Medicina Veterinária e Zootecnia, Universidade de São Paulo, Av. Prof. Orlando Marques de Paiva 87, Cidade Universitária, São Paulo, SP 05508-270, Brazil. E-mail:natalia.gaeta@hotmail.com

Respiratory diseases are among the most important diseases in sheep flocks. Herein was studied the bacterial etiology of respiratory disease and the clinical signs of 99 female and male sheep breed in the states of São Paulo (SP) and Rio de Janeiro (RJ), Brazil. After physical examination of animals, tracheobronchial flushing samples were obtained. The usual bacteria and Mycoplasma spp. were searched, as well as their association with the clinical status and clinical signs of sheep with respiratory disease. The main observed signs were: tachypnea (75\%), increase of rectal temperature (09.4\%), mucopurulent/purulent nasal discharge $(21.9 \%)$, cough $(25 \%)$, dyspnea $(31.2 \%)$, changes of lung sounds at auscultation $(87.5 \%)$ and chest percussion $(28.1 \%)$ in pneumonic sheep. Non-fermenting gram-negative bacteria and Bacillus sp. were the most isolated bacteria. Microorganisms of the Mollicutes class were molecularly (PCR) detected in $33.3 \%$ of the animals. In addition, the specific detection of M. mycoides subsp. capri was described for the first time in sheep from the state of São Paulo, Brazil.
\end{abstract}

INDEX TERMS: Bacteria, lower respiratory tract, sheep, clinics, sheep respiratory disease, Mycoplasma spp., pneumonia, respiratory disease, bacterioses.

\begin{abstract}
RESUMO.- [Bactérias detectadas no trato respiratório inferior de ovinos e a relação com as manifestações clínicas da doença respiratória ovina.] A doença respiratória é uma das doenças mais importantes em rebanhos ovinos. Esta
\end{abstract}

\footnotetext{
${ }^{1}$ Received on May 6, 2019.

Accepted for publication on June 4, 2019.

${ }^{2}$ Departamento de Clínica Médica, Faculdade de Medicina Veterinária e Zootecnia (FMVZ), Universidade de São Paulo (USP), Av. Prof. Orlando Marques de Paiva 87, Cidade Universitária, São Paulo, SP 05508-270, Brazil. *Corresponding author: natalia.gaeta@hotmail.com

${ }^{3}$ Departamento de Medicina Preventiva e Saúde Animal, Faculdade de Medicina Veterinária e Zootecnia (FMVZ), Universidade de São Paulo (USP), Av. Prof. Orlando Marques de Paiva, 87, Cidade Universitária, São Paulo, SP 05508-270.

${ }^{4}$ Laboratório de Micoplasmas, Instituto de Ciências Biomédicas, Universidade de São Paulo (USP), Av. Prof. Lineu Prestes 2415, Cidade Universitária, São Paulo, SP 05508-000.

${ }^{5}$ Unidade de Pesquisa Experimental em Caprinos e Ovinos, Setor de Ovinos e Caprinos, Fazenda Escola de Cachoeiras de Macacu (FECM), Universidade Federal Fluminense (UFF), Rod. João Goularte 1300-1306, Setenta, Cachoeiras de Macacu, RJ 28680-000, Brazil.
}

pesquisa teve como objetivo determinar a etiologia bacteriana da doença respiratória e sua relação com sinais clínicos em ovinos criados nos estados de São Paulo e Rio de Janeiro, Brasil. Noventa e nove ovelhas machos e fêmeas dos Estados de São Paulo (SP) e Rio de Janeiro (RJ) foram estudadas. Após o exame físico, amostras de lavagem traqueobrônquica foram obtidas. A presença de bactérias aeróbias e Mycoplasma spp. foram estudados, assim como a associação entre os microrganismos e estado clínico e sinais clínicos de doença respiratória em ovinos. As principais manifestações clínicas observadas foram: taquipneia $(75 \%)$, alta temperatura retal $(09,4 \%)$, secreção nasal mucopurulenta/purulenta $(21,9 \%)$, tosse (25\%), dispneia $(31,2 \%)$, sons pulmonares alterados na ausculta $(87,5 \%)$ e na percussão torácica $(28,1 \%)$ em ovelhas pneumônicas. Bactérias gram-negativas não fermentadoras e Bacillus sp. foram as bactérias mais isoladas. Microrganismos da classe Mollicutes foram detectados molecularmente (PCR) em 33,3\% dos ovinos. Além disso, descreve-se pela primeira vez no estado de São Paulo, Brasil, a detecção do 
M. mycoides subsp. capri na espécie ovina utilizando a reação de polimerase em cadeia.

TERMOS DE INDEXAÇÃO: Bactérias, trato respiratório inferior, ovinos, ovelhas, clínica, doença respiratória ovina, Mycoplasma spp., pneumonia, bacterioses.

\section{INTRODUCTION}

Sheep respiratory disease is one of the most important diseases in sheep flocks (Marcondes et al. 2011, Radostits et al. 2017) due to its economic losses. In New Zealand, pneumonia in lambs cost NZ\$28.1 million in 2008 (Goodwin-Ray et al. 2008). From 1996 to $2010,10 \%$ of diagnosed diseases in lambs in the "Universidade Federal do Mato Grosso do Sul" were pneumonic related (Almeida et al. 2013). The incidence of pneumonia in sheep and other respiratory diseases in Argentina was 57.9\% (Suárez \& Busetti 2009). In Tanzania, 31.4\% of lungs had pneumonic lesions in slaughter (Mellau et al. 2010). Recently, McRae et al. (2016) detected pneumonic lesions in $28 \%$ of lambs at slaughter in New Zealand.

Important risk factors related to respiratory disease of ruminants are the environmental high temperature and humidity, increased animal density, stress, dust, poor ventilation, and parasites (Goodwin-Ray et al. 2008, Taylor et al. 2010, Scott 2011). Some viruses are considered primary pathogens, changing the epithelial cells, and interfering in the immune response (Bosch et al. 2013), leading to secondary bacterial infections. According to Sharp \& Nettleton (2007) acute respiratory disease is not caused by virus infections alone.

Mannheimia (M.) haemolytica and Pasteurella (P.) multocida are important respiratory pathogens in sheep flocks (Radostits et al. 2017). Both bacteria belong to family Pasteurellaceae, order Pasteurellales (Griffin 2010). These bacteria are part of the respiratory tract microbiota in sheep (Viana et al. 2007) and as stated before, immunosuppression and viral infections predispose to respiratory disease caused by both species (Bosch et al. 2013, Viana et al. 2007). Almost $10 \%$ of pneumonic sheep were positive for $P$. multocida in lungs in Nigeria (Odugbo et al. 2006). Ten sheep died during an outbreak of $M$. haemolytica associated pneumonia in the State of Minas Gerais in 2009 (Araujo et al. 2009).

Mycoplasma spp. belongs to class Mollicutes, order Mycoplasmatales and family Mycoplasmataceae (Razin \& Hayflick 2010). They are the smallest organisms with self-replication (Razin \& Hayflick 2010) and some are detected in healthy and diseased ruminants (Ayling et al. 2004, Kumar et al. 2011, Oliveira et al. 2016, Tortorelli et al. 2017, Gaeta et al. 2018). M. mycoides subsp. capri (Srivastava et al. 2000, Al-Momani et al. 2011, Kumar et al. 2013), M. agalactiae (Kumar et al. 2014), M. capricolum subsp. capricolum (Fischer et al. 2012), M. capripneumoniae (Igbal et al. 2019) and M. ovipneumoniae (George \& Carmichael 1975, Ayling et al. 2004, Dassanayake et al. 2010) are described as important respiratory mycoplasmas for small ruminants.

Sheep with respiratory disease often show depression, inappetence, high rectal temperature, dyspnea, coughing, mucopurulent or purulent nasal discharge and increased cardiac and respiratory rates (Scott 2011). Only a few studies aimed detect the bacterial etiology of pneumonic sheep in Brazil (Coutinho et al. 2009, Marcondes et al. 2011). Therefore, herein it was detected the bacterial etiology of respiratory disease and their relationship to clinical signs of sheep respiratory disease.

\section{MATERIALS AND METHODS}

All procedures were carried out in agreement with the guidelines of the Committee of Ethics on Animal Use (Protocol no. 3498060716).

In this cross-sectional research, 99 male and female sheep from 12 flocks from the States of São Paulo (SP=6) and Rio de Janeiro $(\mathrm{RJ}=6)$ were enrolled in this study, according to a non-probabilistic sampling for convenience.

Animals were classified as healthy and unhealthy (showing clinical signs of respiratory disease) after physical exam (Benesi et al. 2013, Gaeta et al. 2018). Sheep were considered unhealthy if show at least two of the following parameters: respiratory rate more than 30 respiratory movements per minute, coughing, rectal temperature higher than $40^{\circ} \mathrm{C}$ and abnormal sound on thoracic auscultation.

Tracheobronchial wash samples were obtained from both health and pneumonic sheep (Anton \& Mayayo 2007). Briefly, trichotomy and antisepsis using $70 \%$ alcohol, chlorhexidine and iodopovidone were performed in the third part of the trachea. An Intracath ${ }^{\circledast}$ (BD, USA) was introduced by tracheocentesis and 20 to $50 \mathrm{~mL}$ of sterile saline $0.9 \%$ was instilled, recovering up to $5 \mathrm{~mL}$. An aliquot $(500 \mu \mathrm{L})$ was added to Stuart transport media and stored at $4^{\circ} \mathrm{C}$ until the isolation of bacteria. Another aliquot was added to transport media for Mycoplasma spp. containing glycerol and stored in liquid nitrogen.

Tracheal suspensions were inoculated in Brain Heart Infusion broth and the cultures in agar plates were performed by plating $10 \mu \mathrm{L}$ of these samples in MacConkey and Blood agar (5\%). The cultures were incubated for 24 to 72 hours at $37^{\circ} \mathrm{C}$ in aerobic atmosphere. The obtained colonies were noted for their morphology, Gram stained and screened for biochemical tests (Staphylococcus sp.: catalase test, sensitivity to bacitracin and furazolidone and oxidase test; Streptococcus sp.: catalase test, sensitivity to bacitracin, growth at $65 \% \mathrm{NaCl}$, bile-esculin test and growth at $45^{\circ} \mathrm{C}$; Bacillus sp.: catalase test; Klebsiella sp. and non-fermenting bacteria: triple sugar iron growth, production of indole, urease and fenilalanine desaminase, oxidation-fermentation test, motility test, lysine descarboxylation test, use of citrate and malonate, lactose and glucose fermentation, nitrate reduction, Voges-Proskauer test and Methyl-red test) (Murray et al. 1999).

Mycoplasma spp. isolation was performed using solid and liquid SP-4 media (Tully 1995). Agar plates and broths were incubated in aerobiosis at $37^{\circ} \mathrm{C}$ for 15 days. Mycoplasma spp. were screened for producing "fried-egg"-like colonies and differentiated for glucose fermentation and/or arginine hydrolysis without turbiding the broths. Polymerase chain reaction (PCR) was performed to confirm the DNA of Mollicutes in samples (Van Kuppeveld et al. 1992). Then, the PCR positive samples were tested again for M. bovis and M. agalactiae (Chávez González et al. 1995) and M. mycoides subsp. capri (Monnerat et al. 1999).

The association between health status and clinical signs and microbiologic findings were calculated using Chi-square test or Fisher's Exact test. Variables with a $P$-value $<0,05$ were considered significant. All calculations were performed using Software Statistical Package for Social Sciences 16.0 (SPSS, IBM). 


\section{RESULTS}

After clinical examination, the sheep were classified as healthy $(67.7 \%, 67 / 99)$ and pneumonic $(32.32 \%, 32 / 99)$. Clinical signs such as tachypnea, high rectal temperature, mucopurulent/purulent nasal discharge, coughing, dyspnea, abnormal pulmonary sounds on auscultation and thoracic percussion were increased in pneumonic sheep compared to health sheep (Table 1).

Forty-five bacterial isolates were obtained. Bacillus sp., non-fermentative gram-negative bacteria, Streptococcus sp. and Staphylococcus sp. were the main species. P. multocida and M. haemolytica were not isolated (Table 2). Fried-egg-like colonies were observed in $23.3 \%$ (17/73) of samples. The PCR methodology with generic primers for Mollicutes spp. confirmed all isolates of Mollicutes. In addition, PCR was also performed directly in tracheobronchial wash samples, and the DNA of Mollicutes spp. was detected in 45.2\% (33/73) of samples (38\% in pneumonic sheep and $49 \%$ in healthy sheep). M. mycoides subsp. capri (01/33) was detected by PCR. The used specific primers in this study did not allow detect other Mollicute species. No association between species detected and health status were detected.

Regarding to clinical manifestation, only Bacillus sp. was associated to respiratory rate $(P=0.005)$ and submassive/massive sound on thoracic percussion $(P=0.024)$.

Table 1. Clinical signs detected in healthy and pneumonic sheep from the States of São Paulo and Rio de Janeiro, Brazil

\begin{tabular}{|c|c|c|c|}
\hline Clinical signs & $\begin{array}{l}\text { Healthy } \\
\%(\mathrm{~N} / \mathrm{T})\end{array}$ & $\begin{array}{c}\text { Pneumonic } \\
\%(\mathrm{~N} / \mathrm{T})\end{array}$ & P-valor \\
\hline \multicolumn{4}{|l|}{ Body Condition Score } \\
\hline$<2$ & $73.1(49 / 67)$ & $42.9(15 / 32)$ & $0,037^{*}$ \\
\hline$>2$ & $26.9(18 / 67)$ & $53.1(17 / 32)$ & \\
\hline \multicolumn{4}{|l|}{ Heart rate (bpm) } \\
\hline$<120$ & $67.7(46 / 67)$ & $50.0(16 / 32)$ & 0.073 \\
\hline$>120$ & $31.3(21 / 67)$ & $50.0(16 / 32)$ & \\
\hline \multicolumn{4}{|c|}{ Respiratory rate (breaths/min) } \\
\hline$<30$ & $59.7(70 / 67)$ & $25.0(08 / 32)$ & $0.001^{*}$ \\
\hline$>30$ & $40.3(27 / 67)$ & $75.0(24 / 32)$ & \\
\hline \multicolumn{4}{|l|}{ Rectal temperature $\left({ }^{\circ} \mathrm{C}\right)$} \\
\hline $38.5-40.0$ & $97.0(65 / 67)$ & $90.6(29 / 32)$ & $0,011^{*}$ \\
\hline$>40.0$ & $03.0(02 / 67)$ & $09.4(03 / 32)$ & \\
\hline \multicolumn{4}{|l|}{ Nasal discharge } \\
\hline Normal & $98.5(66 / 67)$ & $79.1(25 / 32)$ & $0,001^{*}$ \\
\hline Altered $^{\mathrm{a}}$ & $01.5(01 / 67)$ & $21.9(07 / 32)$ & \\
\hline \multicolumn{4}{|l|}{ Cough } \\
\hline Absent & $97.0(65 / 67)$ & $75.0(24 / 32)$ & $0,001^{*}$ \\
\hline Present & $03.0(02 / 67)$ & $25.0(08 / 32)$ & \\
\hline \multicolumn{4}{|l|}{ Dyspnea } \\
\hline Absent & $94.0(63 / 67)$ & $68.8(22 / 32)$ & $0,001^{*}$ \\
\hline Present & $06.0(04 / 67)$ & $31.2(10 / 32)$ & \\
\hline \multicolumn{4}{|l|}{ Breathing Pattern } \\
\hline Costoabdominal & $98.5(66 / 67)$ & $98.6(29 / 32)$ & 0,098 \\
\hline Costal/Abdominal & $01.5(01 / 67)$ & $09.4(03 / 32)$ & \\
\hline \multicolumn{4}{|l|}{ Laringotracheal sound } \\
\hline Normal & $98.5(66 / 67)$ & $84.4(27 / 32)$ & $0,013^{*}$ \\
\hline Loud & $01.5(01 / 67)$ & $15.6(05 / 32)$ & \\
\hline \multicolumn{4}{|l|}{ Percussion } \\
\hline Clear & $94.0(63 / 67)$ & $71.9(23 / 32)$ & $0,002^{*}$ \\
\hline Submassive/massive & $06.0(04 / 67)$ & $28.1(09 / 32)$ & \\
\hline \multicolumn{4}{|l|}{ Auscultation } \\
\hline Normal & $86.6(58 / 67)$ & $12.5(04 / 32)$ & $<0,001^{*}$ \\
\hline Altered & $13.4(09 / 67)$ & $87.5(28 / 32)$ & \\
\hline Fine Crackles & $06.0(04 / 67)$ & $53.1(17 / 32)$ & $<0,001^{*}$ \\
\hline Thick Crackles & $01.5(01 / 67)$ & $09.4(03 / 32)$ & 0,098 \\
\hline Snoring & $03.0(03 / 67)$ & $18.8(06 / 32)$ & $0,005^{*}$ \\
\hline Whistle & $03.0(03 / 67)$ & $03.1(01 / 32)$ & 1,000 \\
\hline
\end{tabular}


Table 2. Aerobic bacteria detected in tracheobronchial wash samples of sheep in relation to respiratory health status

\begin{tabular}{lcccc}
\hline \multicolumn{1}{c}{ Bacteria } & Healthy \% (N/T) & Pneumonic \% (N/T) & Total \% (N/T) & $P$-value \\
\hline Bacillus sp. & $27.6(08 / 29)$ & $43.7(07 / 16)$ & $33.3(15 / 45)$ & 0.131 \\
Streptococcus sp. & $24.1(07 / 29)$ & - & $15.5(07 / 45)$ & 0.096 \\
Staphylococcus sp. & $20.7(06 / 29)$ & $25.0(04 / 16)$ & $22.2(10 / 45)$ & 0.484 \\
NFGN & $24.1(07 / 29)$ & $18.7(03 / 16)$ & $22.2(10 / 45)$ & 0.980 \\
Klebsiella oxytoca & - & $06.2(01 / 16)$ & $02.2(01 / 45)$ & 0.303 \\
Klebsiella pneumoniae & - & $06.2(01 / 16)$ & $02.2(01 / 45)$ & 0.303
\end{tabular}

$\mathrm{N}=$ number of isolates of the specific bacterium, $\mathrm{T}=$ total number of isolates.

\section{DISCUSSION}

The present study helps to better understand the main bacteria involved in the respiratory disease of Brazilian sheep from the States of São Paulo and Rio de Janeiro, Brazil. Bronchopneumonia was detected in $32.3 \%$ of sheep as detected in other studies in Brazil (Viana et al. 2007) and Ethiopia (Garedew et al. 2010).

Respiratory rate, rectal temperature, nasal discharge, cough, dyspnea, percussion and altered sounds in pulmonary auscultation were increased in pneumonic sheep $(P<0.05)$. These findings confirm the importance of the observed clinical signs of sheep to determine the respiratory health during physical examination (Viana et al. 2007, Legesse et al. 2018).

Opportunistic agents may have a controversy importance due their detection in healthy hosts. Bacillus sp. was the most isolated bacteria, especially in pneumonic sheep. This microbial genera was also detected in other studies with the same propose (Asaye et al. 2015, Megra et al. 2006, Gebremeskel et al. 2017, Yegoraw et al. 2017, Yimer \& Asseged 2007). In fact, Bacillus sp. is an opportunistic infectious agent that belongs to the ovine respiratory tract microbiota (Rajivkumar \& Ghaar 2000, Garedew et al. 2010). The presence of non-anthracis Bacillus microorganism in clinical samples was considered a paradigm for a long time. As mentioned in literature, many infectious agents were previously considered not be pathogenic and became be accepted as pathogenic (Farrar Jr. 1963) as happened with Bacillus sp. considered a non-contaminant in clinical samples (Shimoyama et al. 2017). Otherwise Bacillus cereus is known to be responsible for nosocomial pneumonia in human, and in immunocompromised or immunocompetent human patients (Gray et al. 1999, Miyata et al. 2013, Shimoyama et al. 2017). Bacillus sp. has been isolated from lung tissue (Elshafee 2003) and tracheobronchial flushing samples of cattle (Oliveira et al. 2016, Gaeta et al. 2018). The present study stated the association of clinical signs of sheep, the respiratory disease and the isolation of Bacillus sp. (high respiratory rate and the presence of abnormal sound on thoracic percussion).

Klebsiella oxytoca and K. pneumoniae are virulent bacteria that are often associated with pneumonia in sheep (Ajuwape \& Aregbesola 2002, Patel et al. 2017). Herein, both species were detected, as well was in other studies in Ethiopia et al. (2010) and Iraqi (Al-Sultan 1995).

Mycoplasmas are frequently related to respiratory disease in sheep, and are responsible for important economic losses (Kumar et al. 2012). Mollicutes were detected by PCR in $45.2 \%$ of studied sheep tracheal samples. Al-Momani et al. (2006) obtained similar results in Jordan (35\% samples). In addition, we detected Mollicutes in 38\% of pneumonic and 49\% in healthy sheep. It is well stablished that Mollicutes are part of the respiratory tract microbiota of ruminants, and after a stress, they may become pathogenic. These findings are also in agreement with other studies Swedish flocks (Tauni 2017), and India (Kumar et al. 2012). Mollicutes have also been detected in the lower respiratory tract of calves (Oliveira et al. 2016, Gaeta et al. 2018) in Brazil. M. mycoides subsp. capri was detected by PCR in present study in a healthy sheep. Opportunistic bacteria are easily spread into the flocks, particularly in animals in close proximity. As stated before, any situation that compromises the immune system favors the disease development. During a respiratory outbreak by M. mycoides subsp. capri, Hernandez et al. (2006) described a $60 \%$ mortality in a Mexican goat flock. Animals showed abundant nasal discharge, fever, dyspnea, prostration, ear drop, and decrease in milk production. Depending on the number of affected animals, economic losses might be severe. Finally, most of Mollicutes detected by PCR in studied samples was not specifically identified. This questioned the role of other species of Mollicutes in respiratory disease of sheep, such as M. bovis (Kumar et al. 2012), Acholeplasma sp., and M. arginine (DaMassa et al. 1992).

\section{CONCLUSIONS}

In the present study, Bacillus sp. was the main bacteria detected in both healthy and pneumonic sheep. Important pathogens such as Klebsiella oxytoca and $K$. pneumoniae were both isolated in pneumonic sheep, confirming their importance in the etiology of the disease in the southeastern region of Brazil.

Mollicutes is part of the ruminant's microbiota, but they are also important to ovine pneumonia.

This seems to be the first study that detected Mycoplasma mycoides subsp. capri in the State of São Paulo.

Acknowledgements.- Authors are thankful for all participants and The Brazilian National Council for Scientific and Technological Development for the financial support.

Conflict of interest statement.- The authors have no competing interests

\section{REFERENCES}

Ajuwape T.P. \& Aregbesola E.A. 2002. The bacterial flora of the upper respiratory tract of normal rabbits. Isr. Vet. Med. Assoc. 57:1-5.

Almeida T.L., Brum K.B., Lemos R.A.A., Leal C.R.B. \& Borges F.A. 2013. Doenças de ovinos diagnosticadas no laboratório de anatomia patológica animal da Universidade Federal de Mato Grosso do Sul, Brasil (1996-2010). Pesq. Vet. Bras. 33(1):21-29. <http://dx.doi.org/10.1590/S0100-736X2013000100005> 
Al-Momani W., Abo-Shehada M.N. \& Nicholas R.A. 2011. Seroprevalence of and risk factors for Mycoplasma mycoides subspecies capri infection in small ruminants in Northern Jordan. Trop. Anim. Health Prod. 43(2):463-469. <http://dx.doi.org/10.1007/s11250-010-9717-9><PMid:20960059>

Al-Momani W., Halablab M.A., Abo-Shehada N., Miles K., Mcauliffe L. \& Nicholas R.A.J. 2006. Isolation and molecular identification os small ruminant mycoplasmas in Jordan. Small Rumin. Res. 65(1/2):106-112. <http:// dx.doi.org/10.1016/j.smallrumres.2005.05.022>

Al-Sultan I.I. 1995. Bacterial isolation from pneumonic lungs in sheep. Iraq J. Vet. Sci. 8:213-215.

Anton J.J.R. \& Mayayo L.M.F. 2007. La exploracion clinica del ganado ovino y su entorno. Servet, Zaragoza. 448p.

Araújo M.R., Costa M.C. \& Ecco R. 2009. Ocorrência de pneumonia associada à infecção por Mannheimia haemolytica em ovinos de Minas Gerais. Pesq. Vet. Bras. 29(9):719-724. http://dx.doi.org/10.1590/S0100736X2009000900007.

Asaye M.B. \& Habtamu B.M. 2015. Isolation and characterization of respiratory tract bacterial species from domestic animals with pneumonic lungs from Elphora abattoir, Ethiopia. Int. J. Microbiol. Res. 6:13-19.

Ayling R.D., Bashiruddin S.E. \& Nicholas R.A.J. 2004. Mycoplasma species and related organisms isolated from ruminants in Britain between 1990 and 2000. Vet. Rec. 155(14):413-416. <http://dx.doi.org/10.1136/ vr.155.14.413><PMid:15508840>

Benesi F.., Bertagnon H.G., Wachholz L., Leal M.L.R., Fernandes W.R., Benites N.R. \& Melville P.A. 2013. Microbiota bacteriana e citologia da região traqueobrônquica de bezerros no período neonatal. Pesq. Vet. Bras. 33(6):700-704. <http://dx.doi.org/10.1590/S0100-736X2013000600002>

Bosch A.A.T.M., Biesbroek G., Trzcinski K., Sanders E.A.M. \& Bogaert D. 2013. Viral and bacterial interactions in the upper respiratory tract. PLoS Pathog. 9(1):e1003057. <http://dx.doi.org/10.1371/journal.ppat.1003057> <PMid:23326226>

Chávez González Y.R., Bascuñana C.R., Bölske G., Mattsson J.G., Molina C.F. \& Johansson K.-E. 1995. In vitro amplification of the 16S rRNA genes from Mycoplasma bovis and Mycoplasma agalactiae by PCR. Vet. Microbiol. 47(1-2):183-190. <http://dx.doi.org/10.1016/0378-1135(95)00058-I> $<$ PMid:8604550>

Coutinho A.S., Oliveira Filho J.P., Silva D.P.G., Oliveira A.P., Marcondes J.S., Chiacchio S.B., Paes A.C., Siqueira A.K., Amorim R.M. \& Gonçalves R.C. 2009. Mannheimiose pulmonar experimental em bezerros: swab nasal e nasofaringeano como auxílio diagnóstico. Pesq. Vet. Bras. 29(1):83-88. <http://dx.doi.org/10.1590/S0100-736X2009000100013>

DaMassa A.J., Wakenell P.S. \& Brooks D.L. 1992. Mycoplasmas of gots and sheep. J. Vet. Diagn. Invest. 4(1):101-113. <http://dx.doi. org/10.1177/104063879200400126> <PMid:1554763>

Dassanayake R.P., Shanthalingam S., Herndon C.N., Subramaniam R., Lawrence P.K., Bavananthasivam J., Cassirer E.F., Haldorson G.J., Foreyt W.J., Rurangirwa F.R., Knowles D.P., Besser T.E. \& Srikumaran S. 2010. Mycoplasma ovipneumoniae can predispose bighorn sheep to fatal Mannheimia haemolytica pneumonia. Vet. Microbiol. 145(3/4):354-359. <http://dx.doi.org/10.1016/j.vetmic.2010.04.011><PMid:20466492>

Elshafee S. 2003. Isolation and characterization of aerobic bacteria associated with pneumonic lungs of cattle in Singa slaughter house, Sinnar State. Master's Dissertation, University of Khartoum, Khartoum State, Sudan. 75p.

Farrar Junior W.E. 1963. Serious infections due to "non-pathogenic" organisms of the genus Bacillus. Review of their status as pathogens. Am. J. Med. 34(1):134-141. http://dx.doi.org/10.1016/0002-9343(63)90047-0. PMid:13944444.

Fischer A., Shapiro B., Muriuki C., Heller M., Schnee C., Bongcam-Rudloff E., Vilei E.M., Frey J. \& Jores J. 2012. The origin of the «Mycoplasma mycoides cluster» coincides with domestication of ruminants. PLoS One 7(4):e36150. <http://dx.doi.org/10.1371/journal.pone.0036150><PMid:22558362>
Gaeta N.C., Ribeiro B.L.M., Alemán M.A.R., Yoshihara E., Nassar A.F.C., Marques E.C., Timenetsky J. \& Gregory L. 2018. Bacterial pathogens of the lower respiratory tract of calves from Brazilian rural settlement herds and their association with clinical signs of bovine respiratory disease. Pesq. Vet. Bras. 38(3):374-381. <http://dx.doi.org/10.1590/1678-5150-pvb-5323>

Garedew L., Gelagay A., Yilma R., Zelek A. \& Gelaye E. 2010. Isolation of diverse bacterial species associated with Maedi-Visna infection of sheep in Ethiopia. African J. Microbiol. Res. 4:14-21.

Gebremeskel A., Tesema T., Yegoraw A. \& Mekuria B. 2017. Isolation and characterization of bacterial species from respiratory tracts of cattle slaughtered in Addis Abada City, Central Ethiopia. World's Vet. J. 1(1):1420. <http://dx.doi.org/10.5455/wvj.20170289>

George T.D.S. \& Carmichael L.E. 1975. Isolation of Mycoplasma ovipneumoniae from sheep with chronic pneumonia. Vet. Rec. 97(11):205-206. <http:// dx.doi.org/10.1136/vr.97.11.205><PMid:1162872>

Goodwin-Ray K.A., Stevenson M.A., Heuer C. \& Cogger N. 2008. Economic effect of pneumonia and pleurisy in lambs in New Zealand. N. Z. Vet. J. 56(3):107-114. <http://dx.doi.org/10.1080/00480169.2008.36818> <PMid:18536769>

Gray J., George R.H., Durbin G.M., Ewer A.K., Hocking M.D. \& Morgan M.E.I. 1999. An outbreak of Bacillus cereus respiratory tract infections on a neonatal unit due to contaminated ventilator circuits. J. Hosp. Infect. 41(1):19-22. <http://dx.doi.org/10.1016/S0195-6701(99)90032-4><PMid:9949960>

Griffin D. 2010. Bovine Pasteurellosis and other bacterial infections of the respiratory tract. Vet. Clin. N. Am., Food Anim. Pract. 26(1):57-71. <http:// dx.doi.org/10.1016/j.cvfa.2009.10.010><PMid:20117542>

Hernandez L., Lopez J., St-Jacques M., Ontiveros L., Acosta J. \& Handel K. 2006. Mycoplasma mycoides subsp. capri associated with goat respiratory disease and high flock mortality. Can. Vet. J. 47(4):366-369. <PMid:16642877>

Igbal Y.M., Raffiq P.O., Tauseef B.S., Ahmed B.R., Gopalakrishnan A., Karthik K., Dhama K. \& Vir S.S. 2019. Contagious caprine pleuropneumonia - a comprehensive review. Vet. Q. 39(1):1-25.

II A-S. 1995. Bacterial isolation from pneumonic lungs in sheep. Iraqi J. Vet. Sci. 8:113-118.

Kumar A., Verma A.K., Gangwar N.K. \& Rahal A. 2012. Isolation, characterization and antibiogram of Mycoplasma bovis in sheep pneumonia. Asian J. Anim. Vet. Adv. 7(2):149-157. <http://dx.doi.org/10.3923/ajava.2012.149.157>

Kumar A., Rahal A., Chakraborty S., Verma A.K. \& Dhama K. 2014. Mycoplasma agalactiae, an etiological agent of contagious agalactia in small ruminants: a review. Vet. Med. Int. 2014:1-13. <http://dx.doi.org/10.1155/2014/286752> <PMid:25097796>

Kumar P., Roy A., Bhanderi B.B. \& Pal B. 2011. Isolation, identification and molecular characterization of Mycoplasma isolates from goats of Gujarat State, India. Vet. Arh. 81:443-458.

Kumar V., Rana R., Mehra S. \& Rout P.K. 2013. Isolation and characterization of Mycoplasma mycoides subsp. capri from milk of natural goat astitis cases. ISRN Vet Sci. 593029:5p. <PMid:23762593>

Legesse A., Abayneh T., Mamo G., Gelaye E., Tesfaw L., Yami M. \& Belay A. 2018. Molecular characterization of Mannheimia haemilytica isolates associated with pneumonic cases of sheep in selected areas of central Ethiopia. BMC Microbiol. 18(1):205. <http://dx.doi.org/10.1186/s12866-018-1338-x> <PMid:30518323>

Marcondes J.S., Martins M.T.A., Silva A.A., Rodrigues M.M.P., Ferreira D.O.L., Amorim R.L., Dias A. \& Gonçalves R.C. 2011. Lavado traqueobrônquico por via nasotraqueal como metodologia de colheita de células do trato respiratório de ovinos sadios e portadores de afecções pulmonares. Pesq. Vet. Bras. 31(4):281-286. <http://dx.doi.org/10.1590/S0100-736X2011000400002>

McRae K.M., Baird H.J., Dodds K.G., Bixley M.J. \& Clarke S.M. 2016. Incidence and heritability of ovine pneumonia, and the relationship with production traits in New Zealand sheep. Small Rum. Res. 145:136-141. 
Megra T., Sisay T. \& Asseged B. 2006. The aerobic bacterial flora of the respiratory passageways of healthy goats in Dire Dawa Abattoir, Eastern Ethiopia. Rev. Med. Vet. 157:84-87.

Mellau L.S., Nonga H.E. \& Karimuribo E.D. 2010. A slaughterhouse survey of lung lesions in slaughtered stocks at Arusha, Tanzania. Prev. Vet. Med. 97(2):77-82. <http://dx.doi.org/10.1016/j.prevetmed.2010.08.008> $<$ PMid:20875689>

Miyata J., Tasaka S., Miyazaki M., Yoshida S., Naoki K., Sayama K., Asano K., Fujiwara H., Ohkusu K., Hasegawa N. \& Betsuyaku T. 2013. Bacillus cereus necrotizing pneumonia in a patient with nephrotic syndrome. Intern. Med. 52(1):101-104.<http://dx.doi.org/10.2169/internalmedicine.52.7282> $<$ PMid:23291682>

Monnerat M.P., Thiaucourt F., Poveda J.B., Nicolet J. \& Frey J. 1999. Genetic and serological analysis of lipoprotein LppA in Mycoplasma mycoides subsp. mycoides LC and Mycoplasma mycoides subsp. capri. Clin. Diagn. Lab. Immunol. 6(2):224-230. <PMid:10066658>

Murray P.R., Baron E.J., Pfaller M., Tenover F.C. \& Yolken R. 1999. Manual of Clinical Microbiology. 7th ed. American Society for Microbiology, Washington, DC.

Odugbo M.O., Odama L.E., Umoh J.U. \& Lamorde A.G. 2006. Pasteurella multocida pneumonic infection in sheep: prevalence, clinical and pathological studies. Small Rum. Res. 66(1/3):273-277. <http://dx.doi.org/10.1016/j. smallrumres.2005.09.003>

Oliveira B.A., Gaeta N.C., Ribeiro B.L.M., Alemán M.A.R., Marques L.M., Timenetsky J., Marques J.A., Melville P.A., Marvulle V. \& Gregory L. 2016. Determination of bacterial aetiologic factor on tracheobronchial lavage in relation to clinical signs of bovine respiratory disease. J. Med. Microbiol. 65(10):1137-1142. <http://dx.doi.org/10.1099/jmm.0.000345><PMid:27582268>

Patel S.S., Chauhan H.C., Patel A.C., Shrimali M.D., Patel K.B., Prajapati B.I., Kala J.K., Patel M.G., Rajgor M. \& Patel M.A. 2017. Isolation and identification of Klebsiella pneumoniae from sheep. Int. J. Curr. Microbiol. Appl. Sci. 6(5):331334. <http://dx.doi.org/10.20546/ijcmas.2017.605.037>

Radostits O.M., Gay C., Blood D.C. \& Hinchcliff K.W. 2017. Clinica Veterinária: um tratado de doenças dos bovinos, ovinos, suínos, caprinos e equinos. $10^{\mathrm{a}}$ ed. Guanabara Koogan, Rio de Janeiro. 1737p.

Rajivkumar K.R.C. \& Ghaar P. 2000. Bacteriological studies on pneumonic Gaddi sheep of Himachal Predsh. Indian Vet. J. 77:846-848.

Razin S. \& Hayflick L. 2010. Highlights of mycoplasma research: an historical perspective. Biologicals 38(2):183-190. <http://dx.doi.org/10.1016/j. biologicals.2009.11.008><PMid:20149687>

Scott P.R. 2011. Treatment and control of respiratory disease in sheep. Vet Clin. N. Am., Food Anim. Pract. 27(1):175-186. <http://dx.doi.org/10.1016/j. cvfa.2010.10.016><PMid:21215901>
Sharp J.M. \& Nettleton P.F. 2007. Acute respiratory virus infections, p.207211. In: Aitken I. (Ed), Diseases of Sheep. Blackwell Publishing, New Jersey. http://dx.doi.org/10.1002/9780470753316.ch29.

Shimoyama Y., Umegaki O., Ooi Y., Agui T., Kadono N. \& Minami T. 2017. Bacillus cereus pneumonia in an immunocompetent patient: a case report. JA Clin. Reports 3(1):25. <http://dx.doi.org/10.1186/s40981-017-0096$3><$ PMid:29457069>

Srivastava N.C., Singh V.P., Sunder J., Singh V.P. \& Thiaucourt F. 2000. Isolation of Mycoplasma mycoides small colony type from contagious caprine pleuropneumonia in India. Vet. Rec. 147(18):520-521. <http://dx.doi. org/10.1136/vr.147.18.520 > PMid:11110496>

Suárez V.H. \& Busetti M.R. 2009. Práticas de manejo sanitário e frequência de doenças em ovinos leiteiros na Argentina. Pesq. Vet. Bras. 29(11):931-937.

Tauni F.A. 2017. Association of Mycoplasma ovipneumoniae infection with respiratory disease in Swedish sheep. Degree Project in Veterinary Medicine, Swedish University of Agricultural Sciences, Uppsala, Sweden. 33p.

Taylor J.D., Fulton R.W., Lehenbauer T.W., Step D.L. \& Confer A.W. 2010. The epidemiology of bovine respiratory disease: what is the evidence for predisposing factors? Can Vet J. 51(10):1095-1102. <PMid:21197200>

Tortorelli G., Gaeta N.C., Ribeiro B.L.M., Marques L.M., Timenetsky J. \& Gregory L. 2017. Evaluation of Mollicutes microorganisms in respiratory disease of cattle and their relationship to clinical signs. J. Vet. Intern. Med. 31(4):12151220. <http://dx.doi.org/10.1111/jvim.14721><PMid:28602021>

Tully J. 1995. Culture medium formulation for primary isolation and maintenance of mollicutes, p.33-39. In: Razin S. \& Tully J.(Eds), Molecular and Diagnostic Procedures in Mycoplasmology. Academic Press, Massachusetts. http:// dx.doi.org/10.1016/B978-012583805-4/50005-4.

Van Kuppeveld F.J., Van der Logt J.T., Angulo A.F., Van Zoest M.J., Quint W.G., Niesters H.G., Galama J.M. \& Melchers W.J. 1992. Genus- and species-specific identification of mycoplasmas by $16 \mathrm{~S}$ rRNA amplification. Appl. Environ. Microbiol. 58(8):2606-2615.<PMid:1381174>

Viana L., Gonçalves R.C., Oliveira Filho J.P., Paes A.C. \& Amorim R.M. 2007. Ocorrência de Mannheimia haemolytica e de Pasteurella multocida em ovinos sadios e com enfermidade respiratória. Arq. Bras. Med. Vet. Zootec. 59:1579-1582.

Yegoraw A.A., Gebremeskel A.K., Tesema T.S. \& Birhanu B.T. 2017. Aerobic and anaerobica bacterial isolates from the respiratory tract of sheep slaughteres at Addis Abada Abattoirs Enterprises, Central Ethiopia. J. Vet. Med. Anim. Health 10:284-289.

Yimer N. \& Asseged B. 2007. Aerobic bacterial flora of respiratory tract of healthy sheep slaughtered in Dessie municipal abattoir, northeastern Ethiopia. Rev. Med. Vet. 158:473-478. 